\title{
EVALUASI TERHADAP PELAKSANAAN TUGAS TATA USAHA MADRASAH ALIYAH NEGERI 3 BANJARMASIN
}

\author{
Ade Hermawan, S.Sos, MAP \\ STIA Bina Banua Banjarmasin \\ Email : stiabb08@gmail.com \\ HP : 087814061571
}

\begin{abstract}
ABSTRAK
Pelaksanaan pekerjaan administrasi Madrasah Aliyah Negeri 3 Banjarmasin pada bidang administrasi kepegawaian, administrasi keuangan, administrasi prasarana, administrasi hubungan masyarakat, administrasi kearsipan, dan administrasi kesiswaan berada pada kategori baik. Secara keseluruhan terdapat $67 \%$ responden yang menjawab pelayanan administrasi baik, 31\% menjawab cukup baik, dan 2\% menjawab kurang baik. Artinya dapat disimpulkan bahwa pelaksanaan pekerjaan administrasi Madrasah Aliyah Negeri 3 Banjarmasin sudah baik.
\end{abstract}

Kata kunci : Administrasi Sekolah, Manajemen Tata Usaha

\section{ABSTRACT}

The implementation of the administrative work of Madrasah Aliyah Negeri 3 Banjarmasin in the field of personnel administration, financial administration, infrastructure administration, public relations administration, archive administration, and student administration is in good category. Overall there are $67 \%$ of respondents who answered that the administrative service was good, $31 \%$ answered quite well, and $2 \%$ answered less well. This means that it can be concluded that the implementation of the administrative work of Madrasah Aliyah Negeri 3 Banjarmasin is good.

Keywords: School Administration, Administrative Management 


\section{PENDAHULUAN}

Tata usaha sekolah merupakan ujung tombak pelayanan jasa pendidikan suatu lembaga, yaitu sebagai badan administrasi sekolah yang secara langsung menangani pelayanan didalam internal maupun eksternal sekolah yang mempunyai tugas dan fungsi melayani pelaksanaan pekerjaan- pekerjaan operatif untuk mencapai tujuan dari suatu organisasi, menyediakan keterangan-keterangan bagi pucuk pimpinan organisasi untuk membuat keputusan atau melakukan tindakan yang tepat, dan membantu kelancaran perkembangan organisasi sebagai suatu keseluruhan. Maka, melalui manajemen tata usaha yang baik, juga akan mempengaruhi kualitas pelayanan suatu lembaga.

Keberadaan tenaga tata usaha sekolah dalam proses pembelajaran termasuk dalam hal ini Madrasah Aliyah Negeri 3 Banjarmasin adalah sangat diperlukan. Sebagai salah satu komponen proses pembelajaran, tugas dan fungsi tata usaha tidak dapat dilakukan oleh pendidik. Karena pekerjaan tata usaha bersifat administratif yang tunduk pada aturan sifatnya khusus.

Penelitian ini bertujuan untuk menganalisa Pelaksanaan Tugas Tata Usaha Madrasah Aliyah Negeri 3 Banjarmasin.

\section{TINJAUAN TEORITIS}

Menurut The Liang Gie (1988:13) Tata Usaha adalah segenap rangkaian aktifitas menghimpun, mencatat, mengolah, menggandakan, mengirim dan menyimpan keterangan-keterangan yang diperlukan dalam setiap usaha kerjasama.

Menurut Sutarto (1989:35) Tata Usaha adalah segenap rangkaian penataan yang berupa penghimpunan, pencatatan, pengolahan, penggandaan, pengiriman, penyimpanan, pemeliharaan, penyusunan dan pemusnahan informasi.

Dari perumusan-perumusan diatas tersebut dapat disimpulkan bahwa tata usaha/pekerjaan kantor berhubungan erat dengan masalah keterangan atau warkat. Yang dimaksud dengan keterangan adalah segala sesuatu yang diperoleh melalui pembacaan, pengamatan, pendengaran.

Menurut The Liang Gie (1988:17) Tata Usaha sebagai suatu proses penyelenggaraan mengenai keterangan-keterangan atau warkat pada dasarnya berwujud 6 pola pembuatan yaitu : pertama, Menghimpun : yaitu kegiatan-kegiatan menghimpun mengusahakan tersedianya segala keterangan yang tadinya belum ada atau berserakan di mana-mana sehingga siap untuk digunakan bilamana diperlukan. Kedua, Mencatat : yaitu kegaitan membubuhkan dengan pelbagai peralatan tulis keterangan-keterangan yang diperlukan sehingga berwujud tulisan yang dapat dibaca, dikirim dan disimpan. Ketiga, Mengolah : Yaitu bermacam-macam kegiatan mengerjakan keterangan-keterangan dengan maksud agar dapat disajikan dalam bentuk yang lebih berguna. Keempat, Menggandakan : yaitu kegiitan memperbanyak bahan keterangan dengan berbagai, cara dan alat sebanyak jumlah yang dibutuhkan. Kelima, Mengirim : yaitu kegiatan menyampaikan dengan berbagai cara dan alat-alat satu pihak kepada pihak lain. Keenam, Menyimpan : yaitu kegiatan menaruh dengan pelbagai cara dan alat ditempat tertantu yang aman.

Ketatausahaan selalu ada dalam setiap organisasi serta mempunyai peranan yang dapat mempengaruhi tercapainya tujuan organiasi secara keseluruhan. Secara garis besar tatausaha ini mempunyai 3 peranan pokok yaitu : Pertama, Melayani pelaksanan pekerjaan-pekerjaan operatif untuk mencapai tujuan dari sesuatu organisasi. Kedua Menyediakan keterangan-keterangan bagi pucuk pimpinan organisasi itu untuk membuat keputusan atau melakukan tindakan yang tepat. Ketiga, Membantu kelancaran perkembangan organisasi sebagai suatu keseluruhan (Sutarto, 1989:37).

Tatausaha melayani pelaksanaan pekerjaan operatif dengan menyediakan pelbagai keterangan yang diperlukan. Keterangan-keterangan itu memudahkan tercapainya tujuan yang diinginkan atau memungkinkan pelayanan pekerjaan operatif yang bersangkutan secara lebih baik.

Tatausaha membantu pihak pimpinan organisasi dalam membantu keputusan dan melaksakan dan melakukan tindakan yang tepat. Disini dapat dilihat dengan adanya penyampaian informasi yang berupa laporan dari bawahan adalah merupakan bahan bagi pimpinan dalam membuat suatu keputusan dan dalam melakukan tindakan, disamping itu pula hal ini berkaitan erat dengan fungsi kontrol yang harus dijalankan oleh seorang pimpinan.

Tata usaha mempunyai peranan melancarkan kehidupan dan perkembangan organisasi secara keseluruhan karena fungsinya sebagai sebagai pusat ingatan dan sumber dokumen. Banyak instansi pemerintah atau badan swasta dalam menyelenggarakan kegiatan-kegiatan tidak melakukan pencatatan-pencatatan yang cermat atau memelihara dokumen dengan baik, padahal keterangan-keterangan itu mempunyai arti yang sangat penting sekali untuk bahan penilaian atau 
penyusunan program bagi perkembangan organisasi organisasi tersebut.

Menurut Permendiknas 24/2008

menyebutkan bahwa Fungsi Kepala Tata Usaha sekolah, tugas tata usaha sekolah, tugas administrasi kepegawaian, tugas administrasi keuangan, administrasi sarana prasarana, dan administrasi kehumasan tersaji dalam uraian berikut ini.

Fungsi Kepala Tata Usaha sekolah adalah : Perencana administrasi program dan anggaran, Koordinator administrasi ketatausahaan, Pengelola administrasi program, Penyusun laporan program dan anggaran, dan Pembina staf.

Tugas Tata Usaha (Tenaga Administrasi) Sekolah adalah melaksanakan : Administrasi kepegawaian, Administrasi keuangan, Administrasi sarana dan prasarana, Administrasi kehumasan, Administrasi persuratan dan kearsipan, Administrasi kesiswaan, Teknologi informasi dan komunikasi.

Tugas Tata Usaha sekolah dalam urusan Administrasi Kepegawaian adalah : Mengisi buku induk pegawai, Menyusun daftar urut kepangkatan, Menerbitkan surat tugas/keputusan, Menyusun data dan statistik kepegawaian, Menyusun arsip dan file pegawai, Mengelola daftar hadir pegawai.

Tugas Tata Usaha sekolah dalam urusan administrasi keuangan adalah : Menyimpan dokumen, rekening giro/bank, Menerima dan melakukan pembayaran, Menyimpan arsip/dokumen dan spj keuangan, Membuat laporan penggunaan keuangan, Membuat laporan posisi anggaran (daya serap ), Mencatat keuangan berdasarkan sumber keuanganya pada buku kas umum, pembantu dan tabelaris.

Tugas Tata Usaha sekolah dalam urusan administrasi sarana prasarana adalah : Menyusun daftar kebutuhan sarana dan prasarana, Mencatat dan menginventarisir sarana, Menyimpan dokumen kepemilikan, Membuat daftar inventarisasi ruang.

Tugas Tata Usaha sekolah dalam urusan administrasi kehumasan adalah : Membantu proses kegiatan komite, Menjalin kerja sama dengan pemerintah dan lembaga masyarakat serta keterlibatan pemangku kepentingan (stakeholders), Mencatat dan mendokumentasikan proses kegiatan kehumasan, Mempromosikan sekolah/madarsah dan mengkoordinasikan penelusuran tamatan.

Tugas Tata Usaha sekolah dalam urusan administrasi persuratan dan kearsipan adalah ; Mengelola surat masuk dan keluar, Menggandakan surat/tikrey, Mengelola buku ekspedisi persuratan, Memelihara dan menata kearsipan dan dokumen.
Tugas Tata Usaha sekolah dalam urusan administrasi kesiswaan adalah : Membuat daftar nomor induk siswa, Menyusun daftar keadaan siswa, Membuat usulan peserta ujian, Menginventarisir daftar lulusan, Menyimpan daftar kumpulan nilai (leger), Menginventarisir pendaftaran siswa baru, Mengisi papan data keadaan siswa.

Tugas Tata Usaha sekolah dalam urusan Teknologi informasi dan komunikasi adalah : Mengakses dan mengelola data, Mendokumentasikan administrasi, dan Menginformasikan serta mempromosikan.

\section{METODE PENELITIAN}

Metoda yang dipergunakan dalam penelitian ini adalah metoda Evaluasi, yaitu suatu metoda penelitian yang bertujuan guna melakukan penilaian terhadap keberhasilan pelaksanaan suatu program/ kegiatan. Dalam ini adalah penilaian terhadap keberhasilan pekerjaan administrasi pada Madrasah Aliyah Negeri 3 Banjarmasin.

Populasi dalam penelitian ini adalah seluruh guru PNS yang mengajar pada Madrasah Aliyah Negeri 3 Banjarmasin yang berjumlah 40 orang tidak termasuk Kepala Sekolah dan wakil kepala sekolah madrasah.

Sampel penelitian diambil dari keseluruhan jumlah populasi, yaitu seluruh guru pada Madrasah Aliyah Negeri 3 Banjarmasin. Dengan demikian teknik penarikan sampel yang dipergunakan adalah total sampling. Jumlah sampel yang diambil sebanyak 40 orang.

Teknik pengumpulan data yang dipergunakan dalam penelitian ini adalah sebagai berikut : Pertama, Kuisioner. Yaitu data dikumpulkan dengan menggunakan daftar pertanyaan yang diajukan kepada responden penelitian seputar pelayanan Administrasi yang diberikan oleh Tata Usaha Madrasah Aliyah Negeri 3 Banjarmasin. Kedua, Observasi. Yaitu data dikumpulkan dengan cara turun langsung ke lapangan dengan melakukan pengamatan terhadap fenomena yang menjadi masalah penelitian. Ketiga, Dokumentasi. Yaitu data dikumpulkan dari dokumen-dokumen yang berkaitan dengan masalah penelitian.

Data yang berhasil dikumpulkan diolah kemudian hasilnya dimasukan ke dalam tabel distribusi frekuensi untuk kemudian diberikan penjelasan serta dinterpretasikan. Teknik analisa data dilakukan secara kualitatif.

Tugas Tata Usaha yang dimaksudkan dalam penelitian ini adalah pelaksanaan kerja pegawai Tata Usaha Madrasah Aliyah Negeri 3 Banjarmasin 
dalam mengerjakan tugas pokok dan fungsinya sebagai pelaksana administrasi sekolah dasar yang terdiri dari administrasi kesiswaan, administrasi kepegawaian, administrasi persuratan, administrasi keuangan sekolah, dan administrasi kehumasan.

\section{HASIL DAN PEMBAHASAN}

Madrasah Aliyah Negeri 3 Banjarmasin adalah sekolah berstatus negeri dibawah naungan Kantor Wilayah Kementerian Agama Provinsi Kalimantan Selatan (SK No. 242 tanggal 25/10/1993)dengan Nomor Statistik Sekolah (NSS) : 312637203081/ 134063710041 dan Nomor Pokok sekolah Nasional : 30315578 yang beralamat di Jl. Batu Benawa I no. 61 Banjarmasin.

MAN 3 Banjarmasin memiliki citra moral yang menggambarkan profil madrasah yang diinginkan di masa datang yang diwujudkan dalam Visi madrasah berikut:

Mewujudkan lembaga pendidikan yang melahirkan insan beriman, bertaqwa, berkualitas, berwawasan, berbudaya lingkungan hidup dan berwawasan global.

Visi tersebut di atas mencerminkan cita-cita madrasah yang berorientasi ke depan dengan indikator sebagai berikut : pertama, Menyelenggarakan pembelajaran secara efektif dan efesien berbasis imtaq, TIK dan Lingkungan Hidup dengan didukung oleh tenaga yang profesional handal dan berwawasan, berbudaya lingkungan hidup. Kedua, Menyediakan sarana dan prasarana pembelajaran serta sumber belajar yang memadai berbasis TIK dan lingkungan hidup. Ketiga, Menumbuhkan motivasi berprestasi warga sekolah bidang akademik dan non akademik. Keempat, Menyediakan wahana pembinaan untuk menggali dan mengembangkan potensi siswa dibidang IMTAQ, IPTEK, Olahraga dan Seni secara terarah dan berkelanjutan sebagai kecakapan hidup. Kelima, Menanamkan kesadaran dan memantapkan kepedulian siswa terhadap kebersihan dan kesehatan lingkungan sebagai upaya pelestarian, pencegahan pencemaran dan kerusakan lingkungan hidup. Keenam, Meningkatkan kegiatan partisipatif melalui program keindahan lingkungan dan memperindang hutan sekolah dalam rangka menciptakan / pelestarian lingkungan yang kondusif terhadap aktivitas pendidikan. Ketujuh, Menyediakan wahana komunikasi dan koordinasi antara sekolah, orang tua, siswa, masyarakat dan instansi terkait untuk mendukung Peningkatan mutu Pendidikan dan lingkungan hidup di MAN 3 Banjarmasin.
Misi MAN 3 Banjarmasin adalah : pertama, Melaksanakan pembelajaran, bimbingan dan pembinaan secara efektif. Kedua, Menumbuhkan semangat motivasi berprestasi melalui kegiatan ekstra kurikuler. Ketiga, Menumbuhkan penghayatan terhadap ajaran agama Islam melalui kegiatan keagamaan (tadarus Al qur'an, KSI, maulid Al habsy, pembacaan kitab kuning). Keempat, Memberikan kemampuan akademik, penguasaan IPTEK serta keterampilan untuk melanjutkan kependidikan yang lebih tinggi dan memasuki dunia kerja. Kelima, Mengembangkan nilai-nilai demokratis dan meningkatkan kemandirian serta tanggap terhadap lingkungan.

Tujuan Man 3 Banjarmasin adalah menghasilan lulusan yang : pertama, Memiliki keimanan dan ketaqwaan yang tinggi kepada Allah SWT. Kedua, Memiliki wawasan ilmu pengetahuan dan teknologi yang luas dan mendalam. Ketiga, Memiliki keterampilan keagamaan. Keempat, Memiliki motivasi dan kometmen yang tinggi untuk mencapai prestasi akademik.kelima, Memiliki sikap cinta tanah air, nasionalisme, dan patriotisme. Keenam, Memiliki kemampuan berorganisasi dan jiwa kepemimpinan yang tinggi. Dan ketujuh Memiliki kemampuan bersosialisasi, beradabtasi dengan lingkungan dan mandiri.

MAN 3 Banjarmasin memiliki Jumlah siswa keseluruhan pada tahun ajaran 2020/2021 adalah 731 siswa yang terdiri dari 285 siswa putra dan 446 siswa putri dengan perincian sebagai berikut : pertama, jumlah siswa kelas XII sebanyak 241 siswa (94 putra dan 147 putri). Kedua, jumlah siswa kelas XI sebanyak 255 siswa (101 putra dan 154 putri). Ketiga, jumlah siswa kelas X sebanyak 235 siswa (90 putra dan 145 putri).

MAN 3 Banjarmasin memiliki guru sebanyak 46 orang yang terdiri dari 31 orang guru PNS Depag dan 15 orang guru tidak tetap. Kemudian jumlah pegawai tata usaha sebanyak 23 orang yang terdiri daari 15 orang pegawai PNS Depag dan 8 orang pegawai tidak tetap.

Evaluasi pelaksanaan Tugas Tata Usaha Madrasah Aliyah Negeri 3 Banjarmasin dilakukan berdasarkan hasil pekerjaan Tata Usaha Madrasah Aliyah Negeri 3 Banjarmasin di bidang Administrasi kepegawaian, Administrasi keuangan, Administrasi sarana dan prasarana, Administrasi kehumasan, Administrasi persuratan dan kearsipan, dan Administrasi kesiswaan.
1. Pelaksanaan Pekerjaan Administrasi Kepegawaian
Hasil penelitian mengenai pelaksanaan pekerjaan Administrasi Kepegawaian yang 
dilaksanakan oleh Tata Usaha Madrasah Aliyah Negeri 3 Banjarmasin didasarkan pada penilaian guru sebagai informan dalam penelitian ini yang mengacu pada indikator rincian tugas Tata Usaha Madrasah Aliyah Negeri 3 Banjarmasin di bidang kepegawaian yang meliputi : Mengisi buku induk pegawai, Menyusun daftar urut kepangkatan, Menerbitkan surat tugas/keputusan, Menyusun data dan statistik kepegawaian, Menyusun arsip dan file pegawai, Mengelola daftar hadir pegawai.

Tabel 1 Pelaksanaan Pekerjaan Administrasi Kepegawaian

\begin{tabular}{|c|c|c|c|c|c|}
\hline No & $\begin{array}{l}\text { Administrasi } \\
\text { kepegawaian }\end{array}$ & $\begin{array}{c}\text { Bai } \\
k\end{array}$ & $\begin{array}{l}\text { Cuk } \\
\text { up }\end{array}$ & $\begin{array}{c}\text { Kura } \\
\text { ng }\end{array}$ & $\begin{array}{c}\text { Jumla } \\
\mathrm{h}\end{array}$ \\
\hline 1 & $\begin{array}{l}\text { Mengisi buku } \\
\text { induk pegawai }\end{array}$ & 20 & 19 & 1 & 40 \\
\hline 2 & $\begin{array}{l}\text { Menyusun daftar } \\
\text { urut kepangkatan }\end{array}$ & 30 & 9 & 1 & 40 \\
\hline 3 & $\begin{array}{l}\text { Menerbitkan } \\
\text { surat } \\
\text { tugas/keputusan }\end{array}$ & 24 & 15 & 1 & 40 \\
\hline 4 & $\begin{array}{l}\text { Menyusun data } \\
\text { dan statistik } \\
\text { kepegawaian }\end{array}$ & 21 & 18 & 1 & 40 \\
\hline 5 & $\begin{array}{l}\text { Menyusun arsip } \\
\text { dan file pegawai }\end{array}$ & 25 & 14 & 1 & 40 \\
\hline 6 & $\begin{array}{l}\text { Mengelola daftar } \\
\text { hadir pegawai }\end{array}$ & 36 & 3 & 1 & 40 \\
\hline & Jumlah & $\begin{array}{c}15 \\
6\end{array}$ & 78 & 6 & 240 \\
\hline
\end{tabular}

Tabel 1 menunjukkan tanggapan responden terhadap pelaksanaan pekerjaan Tata Usaha Madrasah Aliyah Negeri 3 Banjarmasin di bidang administrasi kepegawaian yang terdiri dari enam pekerjaan. Dari tanggapan responden terlihat bahwa jawaban terbanyak berada pada kategori baik (156 jawaban). Artinya terdapat kecenderungan bahwa pelaksanaan pelaksanaan pekerjaan Tata Usaha Madrasah Aliyah Negeri 3 Banjarmasin di bidang administrasi kepegawaian adalah baik.

\section{Pelaksanaan Pekerjaan Administrasi} Keuangan

Hasil penelitian mengenai pelaksanaan pekerjaan Administrasi Keuangan yang dilaksanakan oleh Tata Usaha Madrasah Aliyah Negeri 3 Banjarmasin didasarkan pada penilaian guru sebagai informan dalam penelitian ini yang mengacu pada indikator rincian tugas Tata Usaha Madrasah Aliyah Negeri 3 Banjarmasin di bidang keuangan yang meliputi : Menyimpan dokumen, rekening giro/bank, Menerima dan melakukan pembayaran, Menyimpan arsip/dokumen dan spj keuangan, Membuat laporan penggunaan keuangan, Membuat laporan posisi anggaran (daya serap ), Mencatat keuangan berdasarkan sumber keuanganya pada buku kas umum, pembantu dan tabelaris.

Tabel 2 Pelaksanaan Pekerjaan Administrasi Keuangan

\begin{tabular}{|c|c|c|c|c|c|}
\hline No. & Administrasi Keuangan & Baik & Cukup & Kurang & Jumlah \\
\hline 1 & $\begin{array}{l}\text { Menyimpan rekening } \\
\text { bank }\end{array}$ & 24 & 15 & 1 & 40 \\
\hline 2 & $\begin{array}{l}\text { Menerima/melakukan } \\
\text { pembayaran }\end{array}$ & 26 & 13 & 1 & 40 \\
\hline 3 & Menyimpan arsip SPJ & 24 & 15 & 1 & 40 \\
\hline 4 & $\begin{array}{l}\text { Laporan penggunaan } \\
\text { keuangan }\end{array}$ & 25 & 14 & 1 & 40 \\
\hline 5 & Mencatat buku kas & 25 & 14 & 1 & 40 \\
\hline 6 & $\begin{array}{l}\text { Laporan daya serap } \\
\text { anggaran }\end{array}$ & 22 & 27 & 1 & 40 \\
\hline \multicolumn{2}{|r|}{ Jumlah } & 146 & 98 & 6 & 250 \\
\hline
\end{tabular}

Tabel 2 menunjukkan tanggapan responden terhadap pelaksanaan pekerjaan Tata Usaha Madrasah Aliyah Negeri 3 Banjarmasin di bidang administrasi keuangan yang terdiri dari enam pekerjaan. Dari tanggapan responden terlihat bahwa jawaban terbanyak berada pada kategori baik (146 jawaban). Artinya terdapat kecenderungan bahwa pelaksanaan pelaksanaan pekerjaan Tata Usaha Madrasah Aliyah Negeri 3 Banjarmasin di bidang administrasi keuangan adalah cukup baik.

\section{Pelaksanaan Pekerjaan Administrasi Sarana Prasarana}

Hasil penelitian mengenai pelaksanaan pekerjaan Administrasi sarana prasarana yang dilaksanakan oleh Tata Usaha Madrasah Aliyah Negeri 3 Banjarmasin didasarkan pada penilaian guru sebagai informan dalam penelitian ini yang mengacu pada indikator rincian tugas Tata Usaha Madrasah Aliyah Negeri 3 Banjarmasin di bidang sarana prasarana yang meliputi : Menyusun daftar kebutuhan sarana dan prasarana, Mencatat dan menginventarisir sarana, Menyimpan dokumen kepemilikan, Membuat daftar inventarisasi ruang.

Tabel 3 Pelaksanaan Pekerjaan Administrasi Sarana Prasarana

\begin{tabular}{|l|l|c|c|c|c|}
\hline $\begin{array}{l}\text { No } \\
\cdot\end{array}$ & $\begin{array}{l}\text { Administrasi } \\
\text { Sarana } \\
\text { Prasarana }\end{array}$ & $\begin{array}{l}\text { Bai } \\
\mathrm{k}\end{array}$ & $\begin{array}{l}\text { Cuku } \\
\mathrm{p}\end{array}$ & $\begin{array}{l}\text { Kuran } \\
\mathrm{g}\end{array}$ & $\begin{array}{l}\text { Jumla } \\
\mathrm{h}\end{array}$ \\
\hline 1 & $\begin{array}{l}\text { Menyusun } \\
\text { daftar } \\
\text { kebutuhan } \\
\text { sarana dan } \\
\text { prasarana }\end{array}$ & 26 & 13 & 1 & 40 \\
\hline
\end{tabular}




\begin{tabular}{|l|l|c|c|c|c|}
\hline 2 & $\begin{array}{l}\text { Mencatat dan } \\
\text { menginventar } \\
\text { isir sarana }\end{array}$ & 25 & 14 & 1 & 40 \\
\hline 3 & $\begin{array}{l}\text { Menyimpan } \\
\text { dokumen } \\
\text { kepemilikan }\end{array}$ & 24 & 13 & 1 & 40 \\
\hline 4 & $\begin{array}{l}\text { Membuat } \\
\text { daftar } \\
\text { inventarisasi } \\
\text { ruang }\end{array}$ & 26 & 13 & 1 & 40 \\
\hline & Jumlah & 101 & 53 & 4 & 158 \\
\hline
\end{tabular}

Tabel 3 menunjukkan tanggapan responden terhadap pelaksanaan pekerjaan Tata Usaha Madrasah Aliyah Negeri 3 Banjarmasin di bidang administrasi sarana prasarana yang terdiri dari empat pekerjaan. Dari tanggapan responden terlihat bahwa jawaban terbanyak berada pada kategori baik (101 jawaban). Artinya terdapat kecenderungan bahwa pelaksanaan pelaksanaan pekerjaan Tata Usaha Madrasah Aliyah Negeri 3 Banjarmasin di bidang administrasi sarana prasarana adalah baik.

\section{Administrasi Kehumasan}

Hasil penelitian mengenai pelaksanaan pekerjaan Administrasi kehumasan yang dilaksanakan oleh Tata Usaha Madrasah Aliyah Negeri 3 Banjarmasin didasarkan pada penilaian guru sebagai informan dalam penelitian ini yang mengacu pada indikator rincian tugas Tata Usaha Madrasah Aliyah Negeri 3 Banjarmasin di bidang kehumasan yang meliputi : Membantu proses kegiatan komite, Menjalin kerja sama dengan pemerintah dan lembaga masyarakat serta keterlibatan pemangku kepentingan (stakeholders), Mencatat dan mendokumentasikan proses kegiatan kehumasan.

Tabel 4 Pelaksanaan Pekerjaan Administrasi Kehumasan

\begin{tabular}{|l|l|c|c|c|c|}
\hline $\begin{array}{l}\text { N } \\
\text { o. }\end{array}$ & $\begin{array}{l}\text { Administrasi } \\
\text { Kehumasan }\end{array}$ & $\begin{array}{c}\text { Bai } \\
\text { k }\end{array}$ & $\begin{array}{c}\text { Cuk } \\
\text { up }\end{array}$ & $\begin{array}{c}\text { Kura } \\
\text { ng }\end{array}$ & $\begin{array}{c}\text { Juml } \\
\text { ah }\end{array}$ \\
\hline 1 & $\begin{array}{l}\text { Membantu } \\
\text { proses kegiatan } \\
\text { komite }\end{array}$ & 26 & 13 & 1 & 40 \\
\hline 2 & $\begin{array}{l}\text { Membantu } \\
\text { kerjasama } \\
\text { stakeholder }\end{array}$ & 25 & 14 & 1 & 40 \\
\hline 3 & $\begin{array}{l}\text { Mendokumenta } \\
\text { sikan kegiatan } \\
\text { kehumasan }\end{array}$ & 24 & 15 & 1 & 40 \\
\hline 4 & $\begin{array}{l}\text { Mempromosika } \\
\text { n sekolah }\end{array}$ & 26 & 13 & 1 & 40 \\
\hline
\end{tabular}

\begin{tabular}{|c|c|c|c|c|}
\hline Jumlah & $\begin{array}{c}10 \\
1\end{array}$ & 55 & 4 & 160 \\
\hline
\end{tabular}

Tabel 4 menunjukkan tanggapan responden terhadap pelaksanaan pekerjaan Tata Usaha Madrasah Aliyah Negeri 3 Banjarmasin di bidang administrasi kehumasan yang terdiri dari empat pekerjaan. Dari tanggapan responden terlihat bahwa jawaban terbanyak berada pada kategori baik (101 jawaban). Artinya terdapat kecenderungan bahwa pelaksanaan pelaksanaan pekerjaan Tata Usaha Madrasah Aliyah Negeri 3 Banjarmasin di bidang administrasi kehumasan adalah baik.

\section{Administrasi Persuratan Dan Kearsipan}

Hasil penelitian mengenai pelaksanaan pekerjaan Administrasi Persuratan dan kearsipan yang dilaksanakan oleh Tata Usaha Madrasah Aliyah Negeri 3 Banjarmasin didasarkan pada penilaian guru sebagai informan dalam penelitian ini yang mengacu pada indikator rincian tugas Tata Usaha Madrasah Aliyah Negeri 3 Banjarmasin di bidang kearsipan yang meliputi : Mengelola surat masuk dan keluar, Menggandakan surat/tikrey, Mengelola buku ekspedisi persuratan, Memelihara dan menata kearsipan dan dokumen.

Tabel 5 Pelaksanaan Pekerjaan Administrasi Kearsipan

\begin{tabular}{|l|l|c|c|c|c|}
\hline No. & $\begin{array}{l}\text { Administrasi } \\
\text { Kearsipan }\end{array}$ & Baik & Cukup & Kurang & Jumlah \\
\hline 1 & $\begin{array}{l}\text { Mengelola surat } \\
\text { masuk dan keluar }\end{array}$ & 28 & 11 & 1 & 40 \\
\hline 2 & $\begin{array}{l}\text { Menggandakan } \\
\text { surat }\end{array}$ & 28 & 11 & 1 & 40 \\
\hline 3 & $\begin{array}{l}\text { Mengelola buku } \\
\text { ekspedisi } \\
\text { persuratan }\end{array}$ & 27 & 12 & 1 & 40 \\
\hline 4 & $\begin{array}{l}\text { Memelihara dan } \\
\text { menata kearsipan } \\
\text { dan dokumen }\end{array}$ & 26 & 13 & 1 & 40 \\
\hline & 109 & 47 & 4 & 160 \\
\hline
\end{tabular}

Tabel 5 menunjukkan tanggapan responden terhadap pelaksanaan pekerjaan Tata Usaha Madrasah Aliyah Negeri 3 Banjarmasin di bidang administrasi persuratan dan kerarsipan yang terdiri dari empat pekerjaan. Dari tanggapan responden terlihat bahwa jawaban terbanyak berada pada kategori baik (109 jawaban). Artinya terdapat kecenderungan bahwa pelaksanaan pelaksanaan pekerjaan Tata Usaha Madrasah Aliyah Negeri 3 Banjarmasin di bidang administrasi persuratan dan kearsipan adalah baik. 
6. Administrasi Kesiswaan

Hasil penelitian mengenai pelaksanaan pekerjaan Administrasi Kesiswaan yang dilaksanakan oleh Tata Usaha Madrasah Aliyah Negeri 3 Banjarmasin didasarkan pada penilaian guru sebagai informan dalam penelitian ini yang mengacu pada indikator rincian tugas Tata Usaha Madrasah Aliyah Negeri 3 Banjarmasin di bidang kesiswaan yang meliputi : Membuat daftar nomor induk siswa, Menyusun daftar keadaan siswa, Membuat usulan peserta ujian, Menginventarisir daftar lulusan, Menyimpan daftar kumpulan nilai (leger), Menginventarisir pendaftaran siswa baru, Mengisi papan data keadaan siswa.

Tabel 6 Pelaksanaan Pekerjaan Administrasi Kesiswaan

\begin{tabular}{|l|l|c|c|c|c|}
\hline $\begin{array}{l}\text { No } \\
.\end{array}$ & $\begin{array}{l}\text { Administrasi } \\
\text { Kesiswaan }\end{array}$ & $\begin{array}{c}\text { Bai } \\
\mathrm{k}\end{array}$ & $\begin{array}{c}\text { Cuku } \\
\mathrm{p}\end{array}$ & $\begin{array}{c}\text { Kura } \\
\mathrm{ng}\end{array}$ & $\begin{array}{c}\text { Jumla } \\
\mathrm{h}\end{array}$ \\
\hline 1 & $\begin{array}{l}\text { Membuat } \\
\text { daftar nomor } \\
\text { induk siswa }\end{array}$ & 28 & 11 & 1 & 40 \\
\hline 2 & $\begin{array}{l}\text { Menyusun } \\
\text { daftar } \\
\text { keadaan siswa }\end{array}$ & 27 & 12 & 1 & 40 \\
\hline 3 & $\begin{array}{l}\text { Membuat } \\
\text { usulan peserta } \\
\text { ujian, }\end{array}$ & 29 & 10 & 1 & 40 \\
\hline 4 & $\begin{array}{l}\text { Menginventar } \\
\text { isir daftar } \\
\text { lulusan, }\end{array}$ & 28 & 11 & 1 & 40 \\
\hline 5 & $\begin{array}{l}\text { Menyimpan } \\
\text { daftar } \\
\text { kumpulan } \\
\text { nilai (leger), }\end{array}$ & 29 & 10 & 1 & 40 \\
\hline 6 & $\begin{array}{l}\text { Menginventar } \\
\text { isir } \\
\text { pendaftaran } \\
\text { siswa baru, }\end{array}$ & 29 & 10 & 1 & 40 \\
\hline 7 & $\begin{array}{l}\text { Mengisi } \\
\text { papan data } \\
\text { keadaan siswa }\end{array}$ & 27 & 12 & 1 & 40 \\
\hline & Jumlah & 280 & 76 & 7 & 363 \\
\hline
\end{tabular}

Tabel 6 menunjukkan tanggapan responden terhadap pelaksanaan pekerjaan Tata Usaha Madrasah Aliyah Negeri 3 Banjarmasin di bidang administrasi kesiswaan yang terdiri dari tujuh pekerjaan. Dari tanggapan responden terlihat bahwa jawaban terbanyak berada pada kategori baik (280 jawaban). Artinya terdapat kecenderungan bahwa pelaksanaan pelaksanaan pekerjaan Tata Usaha Madrasah Aliyah Negeri 3 Banjarmasin di bidang administrasi kesiswaan adalah baik.
Tabel 7 Rekapitulasi Pelaksanaan Pekerjaan Tata Usaha

\begin{tabular}{|c|c|c|c|c|c|}
\hline No & $\begin{array}{l}\text { Pekerjaan Tata } \\
\text { Usaha }\end{array}$ & Baik & Cukup & Kurang & Jumlah \\
\hline 1 & $\begin{array}{l}\text { Administrasi } \\
\text { kepegawaian }\end{array}$ & 156 & 78 & 6 & \\
\hline 2 & $\begin{array}{l}\text { Administrasi } \\
\text { keuangan }\end{array}$ & 146 & 98 & 6 & \\
\hline 3 & $\begin{array}{l}\text { Administrasi } \\
\text { sarana dan } \\
\text { prasarana }\end{array}$ & 101 & 53 & 4 & \\
\hline 4 & $\begin{array}{l}\text { Administrasi } \\
\text { kehumasan }\end{array}$ & 101 & 55 & 4 & \\
\hline 5 & $\begin{array}{l}\text { Administrasi } \\
\text { persuratan dan } \\
\text { kearsipan }\end{array}$ & 109 & 47 & 4 & \\
\hline 6 & $\begin{array}{l}\text { Administrasi } \\
\text { kesiswaan }\end{array}$ & 280 & 76 & 7 & \\
\hline \multicolumn{2}{|c|}{ Jumlah } & $\begin{array}{l}893 \\
(67 \\
\%)\end{array}$ & $\begin{array}{c}407 \\
(31 \%)\end{array}$ & $\begin{array}{c}31 \\
(2 \%)\end{array}$ & 1.331 \\
\hline
\end{tabular}

Tabel 7 merupakan hasil rekapitulasi jawaban responden terhadap pelaksanaan enam bidang pekerjaan Tata Usaha Madrasah Aliyah Negeri 3 Banjarmasin. Dari tabel tersebut terlihat bahwa pelaksanaan pelaksanaan pekerjaan Tata Usaha Madrasah Aliyah Negeri 3 Banjarmasin dibidang administrasi kepegawaian cendrung baik. Pelaksanaan pelaksanaan pekerjaan Tata Usaha Madrasah Aliyah Negeri 3 Banjarmasin dibidang administrasi keuangan cendrung baik. Pelaksanaan pelaksanaan pekerjaan Tata Usaha Madrasah Aliyah Negeri 3 Banjarmasin dibidang administrasi sarana prasarana cendrung baik. Pelaksanaan pelaksanaan pekerjaan Tata Usaha Madrasah Aliyah Negeri 3 Banjarmasin dibidang administrasi kehumasan cendrung baik. Pelaksanaan pelaksanaan pekerjaan Tata Usaha Madrasah Aliyah Negeri 3 Banjarmasin dibidang administrasi kearsipan cendrung baik. Dan Pelaksanaan pelaksanaan pekerjaan Tata Usaha Madrasah Aliyah Negeri 3 Banjarmasin dibidang administrasi kesiswaan cendrung baik. Secara keseluruhan ada $67 \%$ responden yang menjawab bahwa pelayanan tata usaha adalah baik, $31 \%$ menjawab cukup baik, dan $2 \%$ menjawab kurang baik. Artinya dapat disimpulkan bahwa Pelaksanaan pekerjaan Tata Usaha Madrasah Aliyah Negeri 3 Banjarmasin adalah baik. 


\section{KESIMPULAN}

Pelaksanaan pekerjaan Tata Usaha Madrasah Aliyah Negeri 3 Banjarmasin dibidang administrasi kepegawaian cendrung baik. Pelaksanaan pelaksanaan pekerjaan Tata Usaha Madrasah Aliyah Negeri 3 Banjarmasin dibidang administrasi keuangan cendrung baik. Pelaksanaan pelaksanaan pekerjaan Tata Usaha Madrasah Aliyah Negeri 3 Banjarmasin dibidang administrasi sarana prasarana cendrung baik. Pelaksanaan pelaksanaan pekerjaan Tata Usaha Madrasah Aliyah Negeri 3 Banjarmasin dibidang administrasi kehumasan cendrung baik. Pelaksanaan pelaksanaan pekerjaan Tata Usaha Madrasah Aliyah Negeri 3 Banjarmasin dibidang administrasi kearsipan cendrung baik. Dan Pelaksanaan pelaksanaan pekerjaan Tata Usaha Madrasah Aliyah Negeri 3 Banjarmasin dibidang administrasi kesiswaan cendrung baik. Secara keseluruhan ada $67 \%$ responden yang menjawab bahwa pelayanan tata usaha adalah baik, $31 \%$ menjawab cukup baik, dan $2 \%$ menjawab kurang baik. Artinya dapat disimpulkan bahwa Pelaksanaan pekerjaan Tata Usaha Madrasah Aliyah Negeri 3 Banjarmasin adalah baik.

\section{DAFTAR PUSTAKA}

Abdullah Sani, Ridwan, dkk. Penjaminan Mutu Sekolah, Cet.1 Jakarta: PT.

Bumi Aksara, 2015

Aedi, Nur. Manajemen Pendidik dan Tenaga Kependidikan, Yogyakarta:

Gosyen Publishing, 2016

Arikunto, Suharsimi. Organisasi dan Administrasi Pendidikan Teknologi dan

Kejuruan, Jakarta: RajaGrafindo Persada, 1993

Arikunto, Suharsimi. Prosedur Penelitian Suatu Pendekatan Praktik, Jakarta: Bina Aksaran, 2006

Ismaya, Bambang. Pengelolaan Pendidikan, Bandung: Refika Aditama, 2015

Kasan, Tholib. Teori dan Aplikasi Administrasi

Pendidikan, Jakarta: Studia Press

Lamatenggo Nina dan Hamzah B Uno. Teori Kinerja dan Pengukurannya, Jakarta: Bumi Aksara, 2012

M Daryanto. Administrasi Pendidikan, Jakarta: PT. Asdi Mahasatya, 2006

Minarti, Sri. Manajemen Sekolah, Yogyakarta: Ar-Russ Media, 2016

Nawawi, Hadari. Administrasi Pendidikan, Jakarta: Haji Masagung, 1992
Prihatin, Eka. Teori Administrasi Pendidikan, Bandung: Alfabeta, 2011

Septi Winarsi, Atik dan Ratminto. Manajemen Pelayanan, Yogyakarta: Pustaka Pelajar, 2012

Sugiyono. Metode Penelitian Pendidikan Pendekatan Kuantitatif Kualitatif dan $R \& D$, Bandung: Alfabeta, 2010

Peraturan Menteri Pendidikan Nasional No.24

Tahun 2008 tentang Standar Tenaga Administrasi Sekolah 